PHILIP SELZNICK 
Jurists: Profiles in Legal Theory

William Twining, General Editor 


\section{Philip Selznick}

\section{IDEALS IN THE WORLD}

\section{Martin Krygier}

STANFORD LAW BOOKS

An Imprint of Stanford University Press

Stanford, California 
Stanford University Press

Stanford, California

(C) 2012 by the Board of Trustees of the Leland Stanford Junior

University. All rights reserved.

No part of this book may be reproduced or transmitted in any form or by any means, electronic or mechanical, including photocopying and recording, or in any information storage or retrieval system without the prior written permission of Stanford University Press.

Printed in the United States of America on acid-free, archival-quality paper

Library of Congress Cataloging-in-Publication Data

Krygier, Martin, author.

Philip Selznick : ideals in the world / Martin Krygier.

pages $\mathrm{cm}$. - (Jurists: profiles in legal theory)

Includes bibliographical references and index.

ISBN 978-0-8047-4475-I (cloth: alk. paper)

I. Selznick, Philip, I919-20I0. 2. Sociological jurisprudence.

3. Organizational sociology. 4. Social sciences-Philosophy.

I. Title. II. Series: Jurists-profiles in legal theory.

K37O.K794 2OI2

306.2'5OI-dc23

Typeset by Thompson Type in Io/13 Galliard 
For Jonathan

My son and friend 
